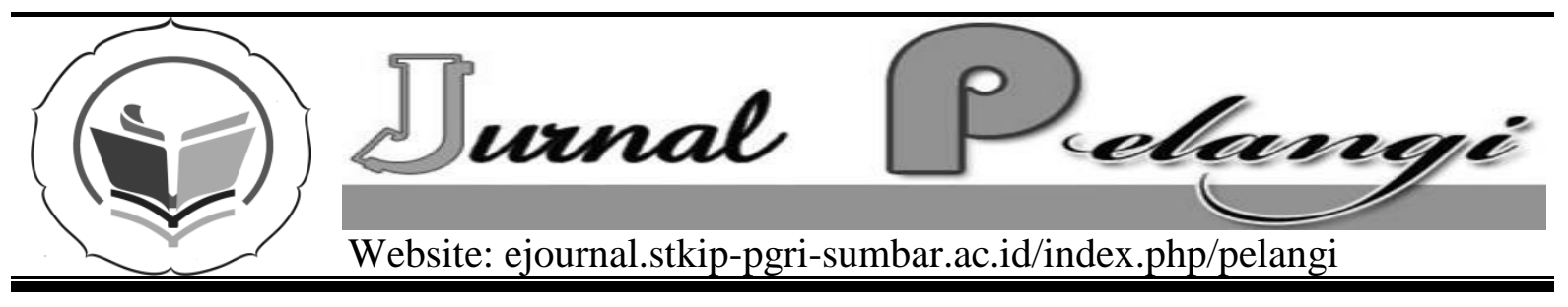

\title{
INDUKSI PEMEKARAN BUNGA (ANTHESIS) TANAMAN MELATI PUTIH (Jasminum sambac L. W. Ait) DENGAN PEMBERIAN PACLOBUTRAZOLPADA BEBERAPA KONSENTRASI
}

\author{
Novi ${ }^{1)}$ dan Rizki ${ }^{2)}$ \\ STKIP PGRI Sumatera Barat \\ novi.s3tia@gmail.com
}

\section{INFO ARTIKEL}

Diterima :01-01-2014

Disetujui :01-12-2014

Kata Kunci:

\section{Melati, \\ Paclobutrazol, Jasminum sambac}

Keywords:
Jasmine, Paclobutrazol, Jasminum sambac

ISSN: 2085-1057

\section{Abstrak}

Bunga melati putih memiliki potensi ekonomi dan social yang besar bagi masyarakat Indonesia khususnya dan dunia umumnya. Kebutuhan melati putih terus meningkat, namun produksi bunga melati putih di Indonesia baru mampu memenuhi sekitar $20 \%$ dari kebutuhan melati di pasaran dunia. Untuk itu diperlukan upaya untuk meningkat kuantitas dan kualitas produksi bunga. Pemanfaatan Zat Penghambat Tumbuh merupakan salah satu solusi untuk meningkatkan produksi bunga melati putih. Salah satu Zat Penghambat Tumbuh yang biasa digunakan adalah paclobutrazol. Sehubungan dengan itu maka dilakukan penelitian dengan judul " Induksi Pemekaran Bunga (Anthesis) Tanaman melati putih (Jasminum sambac L. W. Ait) dengan pemberian paclobutrazol pada beberapa konsentrasi. "Penelitian ini dilakukan pada bulan Maret sampai Juni di greenhouse STKIP PGRI Sumatera Barat. Rancangan percobaan yang digunakan adalah Rancangan Acak Lengkap (RAL) yang terdiri dari 6 perlakuan dan 4 ulangan. Terdiri dari perlakuan $A=$ control $, B=200 \mathrm{ppm}, C=400 \mathrm{ppm}, D=600 \mathrm{ppm}, E=$ $800 \mathrm{ppm}, E=1000 \mathrm{ppm}$. Hasil penelitian menunjukkan bahwa pemberian paclobutrazol pada beberapa konsentrasi tidak memberikan pengaruh terhadap waktu muncul kuncup bunga, waktu mekar bunga (anthesis), dan jumlah bunga melati putih

\section{Abstract}

White jasmine flowers have a bigger potential of economic and social for the people of Indonesia in particular and the world in general. White jasmines keep increasing, but the white jasmine flower production in Indonesia is only able to meet about 20\% of the jasmine need in the world market. Therefore, there must be efforts to increase the quantity and quality of flower production. Inhibiting the growth utilization substance is one solution to increase the 
production of white jasmine flowers. One of the inhibiting of the growth utilization substance commonly used is paclobutrazol. In connection with that, a research conducted entitled "Induction of Proliferation of flowers (anthesis) Plants white jasmine (Jasminum sambac Ait $L W$ ) by administering paclobutrazol at several concentrations. "The research was conducted from March to June in greenhouse of STKIP PGRI West Sumatra. The experimental design used was completely randomized design (CRD), which consists of 6 treatments and 4 replications. Consists of treatment $A=$ control, $B=$ $200 \mathrm{ppm}, C=400 \mathrm{ppm}, D=600 \mathrm{ppm}, E=800 \mathrm{ppm}, E=1000 \mathrm{ppm}$. The results show that administration of paclobutrazol on some concentration does not give effect to emerge when the flower buds, flowers bloom time (anthesis), and the number of white jasmine flowers

\section{PENDAHULUAN}

Dalam kehidupan masyarakat Indonesia, bunga melati putih sudah lama dikenal.Melati merupakan tanaman asli Sri Lanka.Daerah penyebarannya meliputi India, Indonesia, Filipina dan Cina.Sebagai tanaman hias, melati dapat tumbuh dengan baik pada tanah gembur dan subur (Anonimous, 1980).

Melati (Jasminum sambac) merupakan tanaman yang mempunyai banyak manfaat.Selain sebagai tanaman hias, kandungan kimia pada bunga melati yaitu indol, benzyl, livalyacetat, dipercaya dapat mengobati penyakit seperti, sakit kepala, sesak nafas, demam, kelebihan ASI dan sakit mata (Anonimus, 2004).

Mengingat kegunaan bunga melati yang semakin luas dan memasyarakat, maka pada tanggal 5 Juni 1990.Presiden Republik Indonesia mengukuhkan bunga melati menjadi bunga nasional dengan sebutan "Puspa Bangsa".Jenis melati yang dimaksud adalah Jasminum sambac atau yang dikenal dengan tanaman melati putih (Sahutu, 2004).

Bunga melati putih memiliki potensi ekonomi dan social yang besar bagi masyarakat Indonesia khususnya dan dunia umumnya. Kebutuhan akan melati putih dari hari ke hari terus meningkat. Namun produksi bunga melati putih di Indonesia baru mampu memenuhi sekitar 20\% dari kebutuhan melati di pasaran dunia.Untuk itu diperlukan upaya untuk meningkat kuantitas dan kualitas produksi bunga (Rukmana, 1997).

Pemanfaatan Zat Penghambat Tumbuh merupakan salah satu solusi untuk meningkatkan produksi bunga melati putih.Salah satu Zat Penghambat Tumbuh yang biasa digunakan adalah paclobutrazol.Dikatakan sebagai zat penghambat tumbuh karena secara fisiologis paclobutrazol berperan dalam menekan perpanjangan batang karena aktivitas paclobutrazol dapat menghambat biosintesis giberelin (Rosita at al 1996).Akan tetapi paclobutrazol dapat mendorong pembungaan, mendorong pembentukkan pigmen, mencegah etiolasi, memperpanjang perakaran stek, menghambat fase penuaan, memperpanjang umur panen.Dalam konsentrasi rendah paclobutrazol dapat meningkatkan ketahanan tanaman terhadap penyakit (Wattimena, 1999). 
Pemberian paclobutrazol pada tanaman Cosolida orientalis memberikan penampilan yang berbeda terhadap warna daun, warna bunga lebih tajam dan pertumbuhan lebih kompak (Mansuroglu, 2009).Penelitian Rubiyanti (2014) diperoleh hasil bahwa pemberian konsentrasi dan waktu aplikasi memberikan pengaruh terhadap pertumbuhan vegetatif dan generatif tanaman mawar batik.

Siti (2007) menyatakan bahwa penggunaan paclobutrazol memberikan respon yang berbeda terhadap tanaman yang berbeda pula. Hasil penelitian penggunaan paclobutrazol pada tanaman kentang asal kultur jaringan oleh barizi melaporkan bahwa pemberian paclobutrazol pada konsentrasi 500 dan 1000 ppm pada umur 4 minggu setelah tanama ternyata menurunkan jumlah umbi dan bobot umbi dibandingkan kontrol.

Penggunaan paclobutrazol pada tanaman melati putih diharapkan dapat mempercepat masa fase pembungaan dan fase anthesis sehingga lebih cepat bereproduksi.Untuk itu dicoba untuk mencari konsentrasi paclobutrazol yang tepat sehingga tanaman melati putih cepat bereproduksi.

\section{BAHAN DAN METODE}

Bahan yang digunakan pada penelitian ini adalah bibit tanaman melati putih yang telah berumur 2 bulan, paclobutrazol serbuk,alcohol $90 \%$, media tanam, air, kertas label, tissue, kertas saring dan polibag berukuran $2 \mathrm{~kg}(10$ x $30 \mathrm{~cm})$. Sedangkan alat yang digunakan adalah neraca digital, gelas ukur, gelas kimia, batang pengaduk,
Penelitian ini menggunakan metode eksperimen yang disusun dalam Rancangan Acak Lengkap (RAL), yang terdiri dari enam perlakuan dan empat ulangan. Perlakuan yang diberikan yaitu paclobutrazol pada beberapa konsentrasi yaitu: $A=$ control, $B=200 \mathrm{ppm}, \mathrm{C}=400 \mathrm{ppm}$, $\mathrm{D}=600$ ppm, $\mathrm{E}=800$ ppm, $\mathrm{E}=1000$ ppm. Masing-masing perlakuan dilakukan pengulangan yang sama yaitu enam kali, sehingga unit percobaan adalah 24. Data hasil penelitian dianalisis secara deskriptif.

Tahapan pelitian terdiri dari beberapa tahap yaitu tahap pertama persiapan terdiri dari penyediaan media tanam dan bibit, penyediaan paclobutrazol sesuai dengan konsentrasi pada masing-masing perlakuan. Media yang digunakan adalah tanah kebun, pupuk kanda dan sekam padi dengan perbandingan $1: 1$ : 1 . Media tanam dimasukkan ke dalam polibag berukuran 2 kg.Bibit tanaman melati putih yang digunakan adalah bibit yang telah berumur 2 bulan.Tahap kedua adalah pemberian paclobutrazol. Pemberian dilakukan dengan menyiramkan larutan pada media tanam dengan cara membuat lubang di sekeliling tanaman dengan jarak $5 \mathrm{~cm}$ dari batang dan larutan disiramkan ke dalam lubang tersebut. Volume penyiraman yaitu $100 \mathrm{ml}$. Pemberian paclobutrazol dilakukan pada hari kedua setelah bibit dipindahkan ke media perlakuan (bibit berumur lebih kurang 62 hari) Tahapan selanjutnya adalah pemeliharaan yang meliputi penyiraman dan pengendalian gulma. Parameter pengamatan pada penelitian ini meliputi : waktu muncul kuncup bunga, jumlah bunga dan waktu mekarnya bunga (anthesis). 
Data yang didapatkan dianalisis dengan menggunakan analisis sidik ragam. Bila pengaruh perlakuan berbeda nyata maka dilanjutkan dengan uji lanjut Duncan New Multiple Range Test (DNMRT) pada taraf 5\% (Gomez dan Gomez, 1995).

\section{HASIL DAN PEMBAHASAN}

Dari penelitian yang telah dilakukan maka diperoleh hasil sebagai berikut 1. Waktu Muncul Kuncup Bunga

Hasil analisis statistik menunjukkan bahwa pemberian paclobutrazol pada konsentrasi yang berbeda belum memberikan pengaruh terhadap waktu muncul kuncup bunga.

Tabel 1. Pengaruh Pemberian Paclobutrazol pada Beberapa Konsentrasi Terhadap Waktu Muncul Kuncup Bunga Melati Putih

\begin{tabular}{|c|c|}
\hline Paclobutrazol pada beberapa konsentrasi & Rata-rata waktu muncul kuncup (hari) \\
\hline A. Kontrol & 6.25 \\
\hline B. $200 \mathrm{ppm}$ & 3.75 \\
\hline C. $400 \mathrm{ppm}$ & 8.5 \\
\hline D. $600 \mathrm{ppm}$ & 8.0 \\
\hline E. $800 \mathrm{ppm}$ & 11.5 \\
\hline
\end{tabular}

Data rata-rata waktu muncul kuncup dianalisis dengan menggunakan analisis sidik ragam.Dari hasil analisis diperoleh bahwa bahwa perlakuan pemberian paclobutrazol pada konsentrasi 200 - 1000 ppm tidak memberikan pengaruh terhadap waktu muncul kuncup bunga.melati putih.
2. Waktu Anthesis Bunga

Tabel 2 menunjukkan bahwa pemberian paclobutrazol pada konsentrasi $200 \mathrm{ppm}$ 1000 ppm pada saat umur bibit 62 hari ternyata juga tidak memberikan pengaruh terhadap waktu mekarnya bunga melati putih.

Tabel 2. Pengaruh Pemberian Paclobutrazol pada Beberapa Konsentrasi Terhadap Waktu Mekar Bunga Melati Putih

\begin{tabular}{|c|c|}
\hline Paclobutrazol pada beberapa konsentrasi & Rata-rata waktu anthesis (hari) \\
\hline A. Kontrol & 1.48 \\
\hline B. $200 \mathrm{ppm}$ & 1.54 \\
\hline C. $400 \mathrm{ppm}$ & 1.57 \\
\hline D. $600 \mathrm{ppm}$ & 0.71 \\
\hline E. $800 \mathrm{ppm}$ & 0.71 \\
\hline F. $1000 \mathrm{ppm}$ & 0.71 \\
\hline
\end{tabular}

Setelah data ditransformasi dengan menggunakan tranformasi akar dan dianalisis dengan analisis sidik ragam maka diperoleh data seperti pada Tabel 2.Hasil analisis ragam menunjukkan bahwa pemberian paclobutrazol pada konsentrasi 200-1000 ppm tidak berpengaruh terhadap waktu anthesis bunga melati putih. 
3. Jumlah Bunga

Tabel 3.Pengaruh Pemberian Paclobutrazol pada Beberapa Konsentrasi Jumlah Bunga Melati Putih

\begin{tabular}{|c|c|}
\hline Paclobutrazol pada beberapa konsentrasi & Rata-rata jumlah bunga \\
\hline A. Kontrol & 0.835 \\
\hline B. $200 \mathrm{ppm}$ & 0.998 \\
\hline C. $400 \mathrm{ppm}$ & 0.926 \\
\hline D. $600 \mathrm{ppm}$ & 0.707 \\
\hline E. $800 \mathrm{ppm}$ & 0.707 \\
\hline F. $1000 \mathrm{ppm}$ & 0.135 \\
\hline
\end{tabular}

Setelah dilakukan transforamsi akar dan dilanjutkan dengan analisis ragam, pemberian paclobutrazol pada tanaman melati putih umur 62 hari, juga tidak memberikan pengaruh terhadap jumlah bunga melati putih.

Dari Tabel 1,2 dan 3 diketahui bahwa pemberian paclobutrazol dengan konsentrasi 200 - 1000 ppm pada saat tanaman melati putih berumur 62 hari tidak memberikan pengaruh terhadap pertumbuhan generatif.

Pemberian paclobutrazol pada beberapa konsentrasi tidak memberikan pengaruh terhadap fase generatif diduga karena beberapa hal.Pertama konsentrasi GA endogen di dalam tanaman lebih tinggi dibandingkan dengan konsentrasi paclobutrazol yang diberikan sehingga biosintesis GA endogen belum bisa ditekan oleh paclobutrazol yang diberikan. Kedua diduga karena pemberian paclobutrazol pada waktu yang tidak tepat sehingga tanaman tidak memberikan respon.Pemberian paclobutrazol pada saat tanaman melati putih berumur dua bulan diduga telah melewati masa peka terhadap efek paclobutrazol sehingga tidak memperlihatkan respon pertumbuhan pada fase generatif. Salisbury dan Ross (1995) menyatakan bahwa pemberian zat pengatur tumbuh akan lebih efektif bila konsentrasi dan waktu pemberiannya tepat. Ditambahkan oleh Wattimena (1989) yang menyatakan bahwa tanaman tidak akan menunjukkan respon terhadap zat pengatur tumbuh yang bersangkutan apabila tidak diberikan pada masa pekanya. Begitu juga diperkuat oleh pernyataan Davis (1991) bahwa aplikasi waktu paclobutrazol yang terlambat diberikan pada waktu pertumbuhan kemungkinan efek dari paclobutrazol tidak terlihat secara nyata hingga pertumbuhan selanjutnya.

\section{KESIMPULAN DAN SARAN}

Dari penelitian yang telah dilakukan dapat disimpulkan bahwa pemeberian paclobutrazol pada konsentrasi 200-1000 ppm tidak memberikan pengaruh terhadap aspek 
pertumbuhan generatif bunga melati putih yang berumur 2 bulan, mencakup waktu muncul kuncup, waktu anthesis dan jumlah bunga.

Disarankan untuk melakukan penelitan lebih lanjut mengenai waktu yang tepat untuk mengaplikasikan paclobutrazol pada tanaman melati putih.

\section{UCAPAN TERIMAKASIH}

Terbitnya tulisan ini tidak terlepas dari bantuan berbagai pihak, untuk itu penulis ucapkan terima kasih yang sebesar-basarnya kepada Pihak STKIP PGRI Sumatera Barat khususnya pengelola jurnal Pelangi yang telah memberikan kesempatan kepada penulis untuk menulis dijurnal Pelangi. Selanjutnya penulis juga berterima kasih kepada para penyumbang sumber insirasi yang telah memerikan inspirasi bagi penulis untuk mengutip atau menggunakan tulisannya sebagai bahan referensi.

\section{DAFTAR PUSTAKA}

Anonimus. 1980. Tanaman Industri. Jakarta. Balai Pustaka.

Anonimus. 2004. Serba-Serbi Kesehatan: Melati Bunga Indah Yang Menyehatkan. Medan. Waspada Online (http://.Waspada.co.id/serba_ser bi/kesehatan/artikel.php?article_ id=46650\#)

Davis, Tim. D. 1991. Regulation of Tree growth and development with Triazole Compounds. Jurnal of Arboculture 17 (16) : 167-169
Rosita, SDM., Ireng Darwati., Sri Yuliani. 1996. Pengaruh Paclobutrazol Terhadap Pertumbuhan dan Produksi Kencur. Bogor. Balai Penelitian Tanaman Rempah dan Obat.

Rukmana, R. 1997. Usaha Tani Melati. Yogyakarta.Kanisius.

Sahutu, S. 2004. Melati: Penanganan segar dan Pembuatan Minyak Bunga Melati. Jakarta. Penebar Swadaya.

Salisbury, F. B. dan Cleon W, R. 1995.Fisiologi Tumbuhan Jilid 3. Bandung. ITB

Siti, F. S. 2007. Pengaruh Retardan Paclobutrazol Terhadap Pertumbuhan Temu Lawak (Curcuma xanthoriza) Selama Konsentrasi in Vitro.Jurnal Littri, 13 (3) : 93-97

Wattimena, G. A. 1999. Penggunaan Pengatur Tumbuh Tumbuhan Pada Perbanyakan Propagul Tanaman. Bogor. Jurusan Budidaya Pertanian, Fakultas Pertanian, IP 